\title{
Effect of Biological Asset Intensity, Company Size, Ownership Concentration, and Type Firm against Biological Assets Disclosure
}

\author{
YURNIWATI* \\ AMSAL DJUNID \\ FRIDA AMELIA \\ Universitas Andalas
}

\begin{abstract}
Data from the Central Statistics Agency shows Indonesia's agricultural growth rate in the first quarter of 2016 was only 1.85\%. This growth rate decreased significantly, when compared to the same quarter of 2015 which reached $4.03 \%$. This needs to be a concern for the government, society and agricultural companies, because the agricultural sector is one of the backbones in national economic development. The purpose of this study was to examine and analyze the influence of biological assets on the intensity, size of the company, concentration of ownership and type of KAP on the disclosure of biological assets in agricultural companies listed on the Indonesia Stock Exchange for the period 2012-2015. This type of research is descriptive verification. The population in this study were all agricultural companies listed on the Indonesia Stock Exchange, where the sample was selected by purposive sampling method. Through this method 18 companies were selected. Data collection methods are documentary studies. The analytical method used in this study is multiple linear regression analysis. The results of this study indicate that the intensity of biological assets and company size has a significant positive effect on the disclosure of biological assets.
\end{abstract}

Keywords: Biological Asset Intensity, Ownership Concentration, KAP Type, Disclosure of Biological Assets

Intisari: Data Badan Pusat Statistik menunjukkan tingkat pertumbuhan pertanian Indonesia pada kuartal pertama 2016 hanya 1,85\%. Tingkat pertumbuhan ini menurun secara signifikan, jika dibandingkan dengan kuartal yang sama dari tahun 2015 yang mencapai $4.03 \%$. Ini perlu menjadi perhatian bagi pemerintah, masyarakat dan perusahaan pertanian, karena sektor pertanian adalah salah satu tulang punggung dalam pembangunan ekonomi nasional. Tujuan penelitian ini untuk menguji dan menganalisis pengaruh aset biologis terhadap intensitas, ukuran perusahaan, konsentrasi kepemilikan dan jenis KAP pada pengungkapan aset biologis pada perusahaan pertanian yang terdaftar di Bursa Efek Indonesia periode 2012-2015. Jenis penelitian ini adalah verifikasi deskriptif. Populasi dalam penelitian ini adalah semua perusahaan pertanian yang terdaftar di Bursa Efek Indonesia, dimana sampel dipilih

* Corresponding author: yurniwati_feunand@yahoo.co.id 
dengan metode purposive sampling. Melalui metode ini 18 perusahaan dipilih. Metode pengumpulan data adalah studi dokumenter. Metode analisis yang digunakan dalam penelitian ini adalah analisis regresi linier berganda. Hasil penelitian ini menunjukkan bahwa intensitas aset biologis dan ukuran perusahaan memiliki pengaruh positif yang signifikan terhadap pengungkapan aset biologis

Kata Kunci: Intensitas Aset Biologis, Konsentrasi Kepemilikan, Tipe KAP, Pengungkapan Aset Biologis.

\section{Introduction}

\subsection{Background Research}

Indonesia is a country that has the potential for enormous natural resources with a tropical climate. Indonesia is supposed to be advanced in the agricultural sector. However, the condition of Indonesian agriculture is currently precarious, whereby a phenomenon that occurs in Indonesia, a net importer of fruits, livestock and food supplies such as rice, corn, soybeans, and sugar. Indeed, this phenomenon is a condition that is particularly ironic given the era of the 1980s Indonesia became a major exporter of rice in the region. The data showed the Indonesian agriculture growth rate in the first quarter of 2016 is only $1.85 \%$. This growth rate decreased significantly when compared to the same quarter in 2015 , reaching $4.03 \%$. This needs to be a concern for the government, society and the company's agriculture because the agricultural sector is one of the backbones in the development of the national economy. The availability of information becomes an essential part of the decision. Any decision was taken on a variety of considerations derived from such information.

Disclosure of financial statements in its broadest sense means of delivery (release) the information. Meurut Owusu-Ansah (1998) the disclosure of economic information communication is carried out by either the company's financial and non-financial information, quantitative information and other information that reflects the company's position and performance. Therefore, regulators forced companies to deliver information according to the activities carried out in order to minimize the gap between management and investor information (Healy and Palepu, 2001). Disclosure allows the financial 
statements have high quality which will facilitate the investors and users of financial statements to understand and compare the information contained in it (Choi, 2005).

One element of the financial statements is an asset. Paton (1962) defined an asset as good fortune in the form of physical or other forms that had value to a business entity. Financial Accounting Standards Board (1984) defines an asset as the economic benefits that might occur in the future obtained or controlled by a particular entity as a result of past transactions or events. The company according to the standards covering the agricultural sector animal husbandry, forestry, specialty crops, orchards, plantations, agriculture, and fisheries. A company in the agricultural sector this has a unique asset called biological assets (IAS 69).

Biological assets (biological assets) according to IAS 41 is the biological asset a living animal or plant (animal or plant life assets). Thus, it can be said that the biological assets are assets such as living beings who experienced the biological process start to grow, produce, reproduce, so cannot produce themselves and die. Because of a biological process, the company must make a measurement to measure the value of these assets appropriately following the leverage to generate profits in the company.

Biological asset intensity (Intensity of biological assets) illustrates how large a proportion of the investment company against biological assets owned. The intensity of the biological asset can also describe the expectation of cash received if the assets are sold. Previous research conducted by (Routes and Patricia, 2014) obtained results that the intensity of the effect on the disclosure of biological assets biological assets. The size of the company shows, the larger the company, the higher the demands on the disclosure of information than the smaller companies. By disclosing information that more, the company is trying to imply that the company has been applying the principles of proper corporate management (corporate governance). Previous research conducted by (Routes and Patricia,

Freedman and Jaggi (2005), found that the bigger the company, the more the activity of the company. Incentives are reporting companies affected by the ownership structure. Darmawati (2006) states increasingly concentrated ownership of the company; the 
majority shareholder will increasingly dominate the company and the more influence on decision making. The standard was made to ensure the information conveyed to the shareholders to reduce the information asymmetry between managers and external users and to improve the transparency of disclosure (Ding et al., 2007). A company controlled by some investors have a higher demand for public disclosure (Daske et al., 2008). Results of the study (Nuryaman 2009) found that the concentration of ownership affects the level of disclosure. This is in line with research (Routes and Patricia, 2014), which explains that the concentration of corporate ownership disclosure affects the biological assets. Companies with auditors from the Big Four accounting firm to disclose more information than the auditor KAP companies that use non-Big Four. Some studies show a link between compliance with the disclosure of a company audited by KAP Big Four (Hodgdon et al., 2009; Nuryaman, 2009),

It becomes interesting to be related to any disclosure of biological assets should be disclosed to enterprises with IAS 41 disclosure items based on agricultural enterprise and the variables that affect the company made the disclosure. This study is a replication of an earlier study conducted by Routes and Patricia (2014). Differences of this study with previous research, this study was conducted on the first agricultural company listed on the Indonesia Stock Exchange, whereas previous studies conducted on 181 companies registered in countries that have adopted IFRS. Second, the study observation period starts from 2012-2015, whereas previous studies conducted in 2011. Third, the difference in the measurement of the variables used.

\subsection{Motivation Research}

It motivates researchers raised this title is seeing a current phenomenon that happens where Indonesia, a net importer of fruits, livestock and a few main crops though Indonesia itself is a country rich in natural resources and tropical. Indeed, this phenomenon is a condition that is particularly ironic given the era of the 1980s Indonesia became a major exporter of rice in the region. Indonesia slumped agricultural conditions have made many people ask how biological asset management in agricultural companies in Indonesia. So, should the management of biological assets (assets such as plant and 
animal life) agricultural company disclosed in the company's annual report, as well as the accounting policy related to recognition, measurement, and disclosure of biological assets set out in IAS 41 or IAS 69 applied by Indonesian agricultural firm.

\subsection{Research Questions}

1) Is the asset intensity biological effect on the level of disclosure in the company's biological assets agriculture listed in Indonesia Stock Exchange for the period 2012-2015?

2) Is company size affect the level of disclosure in the company's biological assets agriculture listed in Indonesia Stock Exchange for the period 2012-2015?

3) Whether the concentration of ownership affect the level of disclosure in the company's biological assets agriculture listed in Indonesia Stock Exchange for the period 2012-2015?

4) Is the kind of KAP affect the level of disclosure in the company's biological assets agriculture listed in Indonesia Stock Exchange for the period 2012-2015?

\subsection{Research Objectives}

The objectives of this study are:

1) To determine whether there is influence biological asset intensity the level of disclosure in the company's biological assets agriculture listed in Indonesia Stock Exchange for the period 2012-2015

2) To determine whether there is influence the size of the company to the level of disclosure in the company's biological assets agriculture listed in Indonesia Stock Exchange for the period 2012-2015

3) To determine whether there is influence concentration of ownership on the level of disclosure in the company's biological assets agriculture listed in Indonesia Stock Exchange for the period 2012-2015 
4) To determine whether there is influence KAP kind of the level of disclosure in the company's biological assets agriculture listed in Indonesia Stock Exchange fro ofm 2012 to 2015.

\section{Theoretical Framework and Hypothesis Development}

\subsection{Basis Theory}

\subsubsection{Agency theory}

Agency theory is a theory that explains the relationship between the owners of capital (principal) is the investor to the manager (agent). Jensen and Meckling (1976) explain that the agency theory as a contract between one or more person (principal) that employs another person (the agent), to perform a service and giving decision-making authority.

\subsubsection{Stakeholder theory}

Freeman (1984) defines stakeholders as "any group or individual who can affect or be affected by the achievement of an organization's objectives." That the stakeholder is any group or individual, who can affect or be affected by the process of achieving the goals of an organization. This theory states that all stakeholders have the right to obtain information about how their activities affect the organization (Deegan in Ihyaul, 2009).

\subsubsection{Biological assets}

Biological assets under IAS 41 is an asset such as animal or plant life. Biological transformation is a process of growth, degeneration, production, and procreation caused qualitative and quantitative changes in living beings and generated new assets in the form of agricultural products or additional biological assets on the same type.

\subsubsection{Disclosure of Biological Assets}

According to Owusu-Ansah (1998), the disclosure of economic information communication is carried out by either the company's financial and non-financial information, quantitative information and other information that reflects the company's position and performance. An entity shall disclose profit aggregate biological assets or losses arising during the period. A description of each group of biological assets, if not 
disclosed as information published with the financial statements, the entity shall explain the nature of activities involving each group of biological assets. The entity shall disclose the methods and assumptions significant applied in determining the fair value of each group of agricultural produce at the point of harvest and each group of biological assets. Further, the entity shall disclose the fair value less costs to sell of agricultural products that have been harvested during the period; an entity shall disclose the existence and carrying amounts of biological assets. Furthermore, the entity shall present a list of reconciliation of changes in the carrying value of the biological assets between the beginning and end of the period (IAS 41 Paragraphs 40-50). Disclosure items with IAS 41 biological assets contained in Appendix Table 2.1.

\subsubsection{Biological Asset Intensity}

Biological assets are resources in the form of living beings who experienced the biological transformation as a result of past events and to provide benefits to the company in the future. Biological transformation leads to changes in the value of assets through increases (improving the quality of an animal or plant), decrease (reduction or loss of quality of animal or plant), breeding (procreation) and production.

\subsubsection{Company size}

Machfoedz (1994) states that the size of the company is a scale that can classify the company into large and small companies in various ways such as total assets, the value of the stock market, the average level of sales and sales amount.

\subsubsection{Ownership concentration}

According to the classical theory of the managerial firm (Baumol, 1959; Galbaraith 1967) as cited by Goriz and Fumas (1996), the type of ownership and control of a company is divided into two. First, the company is owned by many shareholders. Second, the company owned and controlled by management. A concentration of ownership (ownership concentration) is a measure of the distribution of decision-making power (voting power distribution) for the owners or managers. 


\subsubsection{Type KAP}

According to Jensen and Meckling (1976) states that auditing is a mechanism to reduce agency costs. With the company's audited financial statements will require a KAP (Public Accounting Firm) quality. Companies with high agency costs will tend to use the services of an accounting firm affiliated with the Big Four.

\subsection{Hypothesis development}

\subsubsection{Biological asset intensity affects the disclosure of biological assets}

In a study by Silva et al. (2012) explain that the reporting of biological assets ensure compliance with the disclosure in order to provide information to users of financial statements. Previous research also obtains the result that the intensity of the effect on the disclosure of biological assets biological assets (Route and Patricia, 2014), Based on the above the first hypothesis to be tested in this study are as follows:

H1. Biological asset intensity affects the biological asset disclosure.

\subsubsection{The size of the company influences the biological asset disclosure}

Large companies tend to have a percentage of capital and greater agency costs (Jensen and Meckling, 1976) that requires the disclosure of information to stakeholders, particularly financial analysts. Results of the study (Nuryaman 2009; Routes and Patricia, 2014) found results in firm size affect the level of disclosure. Based on the above second hypothesis to be tested in this study are as follows:

H2. Company size affects the biological asset disclosure.

\subsubsection{A concentration of ownership affects the disclosure of biological assets}

A company controlled by some investors have a higher demand for public disclosure (Daske et al., 2013). Results of the study (Nuryaman 2009; Routes and Patricia, 2014) found results that affect the level of ownership concentration disclosure of biological assets. Based on the above third hypothesis to be tested in this study are as follows:

H3. A concentration of ownership affects the disclosure of biological assets. 


\subsubsection{Type KAP affect the disclosure of biological assets}

Firms with Big Four auditors to disclose more information than the auditor KAP companies that use non-Big Four. Some studies show a link between compliance with the disclosure of a company audited by the Big Four (Hodgdon et al., 2009; Nuryaman, 2009)

\section{H4.KAP type of biological effect on asset disclosure}

\section{Research method}

\subsection{Population and Sample}

The population in this study are all agricultural companies listed on the Indonesia Stock Exchange. The sample was selected from the population of the company based on purposive sampling. The study period was in 2012-2015. The sample selection using purposive sampling method with the criteria listed in Table 4.1

Table1

Criteria for Research Samples

\begin{tabular}{|l|c|}
\hline Information & Number of Companies \\
\hline $\begin{array}{l}\text { Agricultural companies listed in Indonesia Stock } \\
\text { Exchange }\end{array}$ & $\mathbf{2 5}$ \\
\hline $\begin{array}{l}\text { Agricultural companies that are not listed on the Indonesia } \\
\text { Stock Exchange for the period 2012-2015 } \\
\text { An agricultural company that does not publish annual } \\
\text { financial statements audited during the observation period } \\
2012-2015\end{array}$ & \\
\hline Companies that do not meet the criteria & (2) \\
\hline Companies that meet criteria & $\mathbf{1 8}$ \\
\hline
\end{tabular}

Source: Indonesia Stock Exchange (IDX) processed 


\subsection{Measurement and Operational Definition of Variables}

\subsubsection{Dependent variables}

\section{Disclosure of Biological Assets ( $Y$ )}

The dependent variable in this study is the disclosure of biological assets, the disclosure of items presented in Table 2.1 in the appendix. Disclosure index that will be used to measure the biological asset disclosure obtained in the following ways, if any items disclosed in the financial statements then given a score of 1 (one) and a score of 0 (zero) if not disclosed. Furthermore, to measure the area of disclosure by comparing the total scores obtained (n) with a total score which is required under IAS 41, or expressed by the formula Wallace index:

$$
=\mathrm{X} 100 \% \frac{n}{40}
$$

\subsubsection{Independent variables}

\section{Biological asset intensity (X1)}

Biological asset intensity (Intensity of biological assets) illustrates how much the investment company against biological assets owned by the company. Measurements related to biological assets according to Routes and Patricia (2014) is

$$
\text { Biological asset intensity }=\frac{\text { Biological Asset }}{\text { Total Asset }}
$$

The size of the company (X2)

The size of the company is a scale that can classify the company into large and small companies in various ways such as total assets, the value of the stock market, the average level of sales and sales amount. The size of the assets used to measure the size of the company, which is measured as the logarithm of total assets.

$$
\text { SIZE }=\text { Ln (Total Assets) }
$$

A concentration of ownership (X3)

A concentration of ownership (ownership concentration) is a measure of the distribution of power in decision-making (voting power distribution) for the owners or managers. 
Measurement of concentration of ownership in this study using measurements according to Routes and Patricia (2014) by proxy as follows:

$$
\text { A concentration of ownership }=\frac{\text { Amount of stock ownership }}{\text { amounts of stock in market }} \times 100
$$

Type KAP (X4)

Measurement types KAP using dummy variables are variables used to quantify qualitative variables. This variable was measured by using a dummy number to distinguish between KAP KAP Big Four and Non-Big Four.

$$
\begin{aligned}
& 1=\text { affiliated with the big four, } \\
& 0=\text { non-big four }
\end{aligned}
$$

\subsection{Method of Analysis}

\subsubsection{Descriptive statistics}

Descriptive statistics provide a picture or description of a data seen from the average (mean), standard deviation, variance, maximum, minimum of each sample (Ghozali, 2016), processed using SPSS (Statistical Package for Social Science) Ver 23.0.

\subsubsection{Classic assumption test}

Before testing the hypothesis, then the first classical assumption test, which consists of:

\subsubsection{Normality test}

Normality test aims to test whether the regression model or residual confounding variables have a normal distribution. Residual normality test research data by using a one-sample Kolmogorov-Smirnov test (KS), which if level of significance> 0.05 then the normal distribution of data (Ghozali, 2016).

\subsubsection{Multicolinearity test}

Multicollinearity test aims to test whether the regression model that formed no high or perfect correlation between the independent variables or not. To detect multicollinearity can be seen from the value of tolerance and variance factors (VIF). If VIF $<10$ and the value of TOL (tolerance) $>0.10$ then the model is expressed not contain multicollinearity (Ghozali, 2016). 


\subsubsection{Autocorrelation test}

According to Ghozali autocorrelation test aims to see whether in a linear regression model was no correlation between bullies error in period $t$ with bullies error in period $t$ 1 (previous). In this study was used to detect the general rule of thumb according to Singgih (2010) :

1) Figures DW below -2 means there is positive autocorrelation.

2) Figures DW between -2 to +2 , meaning no autocorrelation.

3) Figures DW above +2 means there is negative autocorrelation.

\subsubsection{Heteroskedasticity test}

Heteroskedasticity test aims to test whether the regression model occurred inequality variance of the residuals of the observations to other observations (Ghozali, 2016). One way to detect the presence or absence of heteroskedasticity is to use a scatterplot chart between the predicted values of the dependent variable (dependent) is ZPRED with residual SRESID. By looking at the graph plot between the predicted values of the dependent variable with a residual from the analysis as follows:

1. If there are specific patterns, such as dots that no specific form regular patterns (wavy, widened, then narrowed), it indicates there has been a heteroskedasticity.

2. If there is no clear pattern, as well as the points spread above and below zero on the Y-axis, then there is no heteroscedasticity.

\subsubsection{Testing Hypothesis}

\subsubsection{Regression analysis}

Multiple regression analysis in this study is used to test the intensity of biological assets, company size and concentration of ownership and type of audit on the disclosure of biological assets. The multiple regression models in this study as follows.

$\mathrm{Y}^{\prime}=\mathrm{a}+\mathrm{b} 1 \mathrm{x} 1+\mathrm{b} 2 \mathrm{X} 2+\mathrm{b} 3 \mathrm{X} 3+\mathrm{b} 4 \mathrm{X} 4+\mathrm{e}$

Which in this study:

$\mathrm{Y}^{\prime}=$ Disclosure of Biological Assets

$\mathrm{a}=$ intercept (constant) is approximate value of $\mathrm{Y}$ if $\mathrm{X}=0$

$\mathrm{b} 1$ = regression coefficients for $\mathrm{X} 1$ 
$\mathrm{b} 2$ = regression coefficient for $\mathrm{X} 2$

$\mathrm{b} 3$ = regression coefficient for $\mathrm{X} 3$

$\mathrm{b} 4=$ regression coefficient for $\mathrm{X} 4$

$\mathrm{e}=$ 'residual values (the values of other variables not included in the equation

\subsubsection{Test Coefficient of Determination}

According to Ghozali (2016), coefficient determination essentially measures how far the model's ability to explain variations in the dependent variable. A coefficient of determination is between zero and one. $\mathrm{R}^{2}$ small value means the ability of independent variables in explaining the variation is very limited dependent variables.

\subsubsection{T statistical test (partially)}

This test is used to show how far the influence of the independent variables individually in explaining the variation of the dependent variable. If the p-value is smaller than the prescribed level of significant $5 \%$, then the t-test showed that the partially independent variables affect the dependent variable (Ghozali, 2016). Acceptance or rejection of the hypothesis is done with the following criteria:

a) When $\mathrm{t}>\mathrm{t}$ table or a probability smaller than the significance level (Sig <0.05), the Ha Ho accepted and rejected, the independent variables affect the dependent variable.

b) When $\mathrm{t}<\mathrm{t}$ table or a probability smaller than the significance level ( $\mathrm{Sig}>0.05)$ then Ha Ho accepted and rejected, not independent variables affect the dependent variable.

\section{Results and Discussion}

\subsection{Research result}

\subsubsection{Descriptive statistics}

Descriptive statistics include the maximum, minimum, average and standard deviation. The sample used in this study were 18 agricultural companies within 
a period of 4 years (2012 to 2015) so that the sum of all the samples used were 72 samples.

Table 2

Descriptive statistics

\begin{tabular}{|l|l|l|l|l|l|}
\hline & & Ninimum & maximum & mean & $\begin{array}{l}\text { Std. } \\
\text { deviation }\end{array}$ \\
\hline Biological asset intensity & 72 & 06 &, 71 &, 2843 &, 17700 \\
size of company & 72 & 11.04 & 13.39 & 12.6260 &, 60813 \\
concentration of ownership & 72 & 26.37 & 83.46 & 51.1714 & 15.27734 \\
type KAP & 72 &, 00 & 1.00 &, 3472 &, 47943 \\
Disclosure of biological assets & 72 &, 35 &, 78 &, 5036 &, 09053 \\
Valid N (listwise) & 72 & & & & \\
\hline
\end{tabular}

\subsubsection{Classical Assumption Test Results}

\subsubsection{Normality test}

Table 3

Normality Test Results Research Variables

One-Sample Kolmogorov-Smirnov Test

\begin{tabular}{|ll|l|}
\hline & & Residual unstandardized \\
\hline Normal Parametersa, b & mean & 72 \\
& Std. deviation & 0000000 \\
& Absolute &, 05765560 \\
Most Extreme Differences & positive &, 127 \\
& Negative & -074 \\
Kolmogorov-Smirnov Z & & 1.074 \\
Asymp. Sig. (2-tailed) & &, 199 \\
\hline
\end{tabular}
a. Test distribution is Normal.
b. Calculated from data. 
Version SPSS 23.0 processing results obtained Kolmogorov data processing result Smirnov model values obtained unstandardized significance> 0.05 is 0.199 (Asymp. Sig) means that the data are normally distributed.

\subsubsection{Multicollinearity Test}

Table 4

Coefficients Multikolinearisity Test Results

\begin{tabular}{|c|c|c|c|c|c|c|c|}
\hline \multirow[t]{2}{*}{ Model } & \multicolumn{2}{|c|}{$\begin{array}{l}\text { Coefficients } \\
\text { unstandardized }\end{array}$} & \multirow{2}{*}{\begin{tabular}{|l}
$\begin{array}{l}\text { standardized } \\
\text { Coefficients }\end{array}$ \\
Beta \\
\end{tabular}} & \multirow[b]{2}{*}{$\mathrm{T}$} & \multirow[b]{2}{*}{ Sig. } & \multicolumn{2}{|c|}{ collinearity Statistics } \\
\hline & B & $\begin{array}{l}\text { Std. } \\
\text { Error }\end{array}$ & & & & tolerance & VIF \\
\hline (Constant) & -1.021 & 162 & & -6.286 & 000 & & \\
\hline Biological asset intensity &, 230 & 042 &, 450 & 5,498 & 000 &, 905 & 1,105 \\
\hline size of company &, 119 & 013 &, 801 & 9.091 & 000 &, 779 & 1,284 \\
\hline concentration of ownership &,- 001 & .001 &,- 113 & -1.291 & 201 &, 792 & 1,262 \\
\hline type KAP &,- 038 & .016 &,- 202 & -2.349 & 022 & , 819 & 1,221 \\
\hline
\end{tabular}

a. Dependent Variable: Disclosure of biological assets

Based on the table above shows that no independent variable has a value of less than 0.100 Tolerance everything $>0,100$ and VIF $<10$ means that there is no correlation between the independent variables. Thus, it can be said not happen multicollinearity.

\subsubsection{Autocorrelation Test}

Table 5

Autocorrelation Test Results

\begin{tabular}{|c|c|c|c|c|c|}
\hline \multicolumn{6}{|c|}{ Model Summaryb } \\
\hline Model & $\mathrm{R}$ & R Square & $\begin{array}{ll}\text { Adjusted } & \mathrm{R} \\
\text { Square } & \end{array}$ & $\begin{array}{l}\text { Std. Error of the } \\
\text { Estimate }\end{array}$ & $\begin{array}{l}\text { Durbin- } \\
\text { Watson }\end{array}$ \\
\hline \begin{tabular}{l|l}
$\mathrm{d}$ & 1
\end{tabular} & , 771a &, 594 & 570 & , 05935 & 1,050 \\
\hline
\end{tabular}


a. Predictors: (Constant), type KAP, Biological asset intensity, concentration of ownership, size of a company

b. Dependent Variable: Disclosure of biological assets

Based on the table above obtained the value of Durbin-Watson (DW count) of 1.050. Based on predetermined criteria DW count is between -2 and 2, i.e., $2 \leq 2 \leq 2$ then this means no autocorrelation.

\subsubsection{HeteroskidastityTest}

Figure 1

Testing Heteroskedasticity

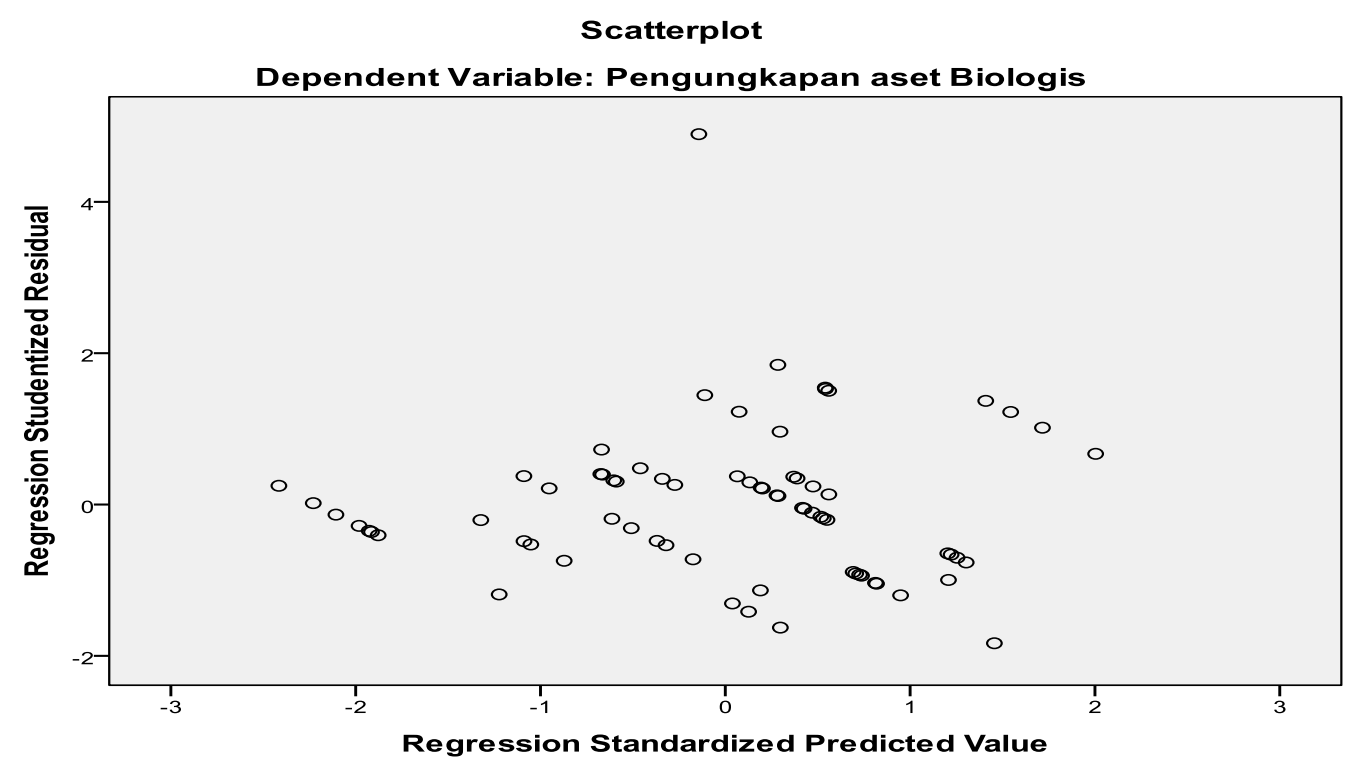

Based on the output of the test results, as seen from the picture above is known that the point - the point is not to form a clear pattern. As can be seen the point - the point spread above and below the number 0 on the axis Y. Thus, it can be concluded that there is no heteroscedasticity in the regression model. 


\subsubsection{Hypothesis testing}

\subsubsection{Regression analysis}

Table 6

Multiple Linear Regression Test Results

\begin{tabular}{|c|c|c|c|c|c|c|}
\hline \multirow{2}{*}{\multicolumn{2}{|c|}{ Model }} & \multicolumn{2}{|c|}{$\begin{array}{l}\text { Coefficients } \\
\text { unstandardized }\end{array}$} & \multirow{2}{*}{$\begin{array}{l}\text { standardized } \\
\text { Coefficients }\end{array}$} & \multirow[b]{2}{*}{$\mathrm{T}$} & \multirow[b]{2}{*}{ Sig. } \\
\hline & & B & $\begin{array}{l}\text { Std. } \\
\text { Error }\end{array}$ & & & \\
\hline \multirow[t]{5}{*}{1} & (Constant) & -1.021 &, 162 & & -6.286 &, 000 \\
\hline & Biological asset intensity &, 230 &, 042 &, 450 & 5,498 &, 000 \\
\hline & size of company &, 119 &, 013 &, 801 & 9.091 &, 000 \\
\hline & concentration of ownership &,- 001 & .001 &,- 113 & -1.291 &, 201 \\
\hline & type KAP &,- 038 & .016 &,- 202 & -2.349 &, 022 \\
\hline
\end{tabular}

Based on the results of the above output can be made as the following equation:

$\mathrm{Y}^{\prime}=\mathrm{a}+\mathrm{b} 1 \mathrm{x} 1+\mathrm{b} 2 \mathrm{X} 2+\mathrm{b} 3 \mathrm{X} 3+\mathrm{b} 4 \mathrm{X} 4+\mathrm{e}$

$\mathrm{Y}^{\prime}=-1.021+0,230 \mathrm{X} 1+0,119 \mathrm{X} 2-0,001 \mathrm{X} 3-0,038 \mathrm{X} 4+\mathrm{e}$

\subsubsection{Coefficient Determination Test Results}

Table 7

Coefficient Determination Test Results

\begin{tabular}{|c|c|c|c|c|c|c|}
\hline \multicolumn{7}{|c|}{ Model Summaryb } \\
\hline & & $\mathrm{R}$ & R Square & $\begin{array}{ll}\text { Adjusted } & \mathrm{R} \\
\text { Square } & \end{array}$ & $\begin{array}{l}\text { Std. Error of the } \\
\text { Estimate }\end{array}$ & $\begin{array}{l}\text { Durbin- } \\
\text { Watson }\end{array}$ \\
\hline 0 & 1 &, $771 \mathrm{a}$ &, 594 & 570 &, 05935 & 1,050 \\
\hline
\end{tabular}

a. Predictors: (Constant), type KAP, Biological asset intensity, concentration of ownership, size of a company

b. Dependent Variable: Disclosure of biological assets 
According to the table above seen great value $R 2$ by 0594 which means that the dependent variable that can be explained by the independent variable of $59.4 \%$ which is biological variable contribution asset intensity, company size, concentration of ownership and type of KAP on the disclosure of biological assets and the remaining $40.6 \%$ affected by other variables not examined in this study.

\subsubsection{Test Results Statistics $t$ (t-Test)}

Table 8

Test Results Statistics t (t-Test)

\begin{tabular}{|c|c|c|c|c|c|c|}
\hline \multirow{2}{*}{\multicolumn{2}{|c|}{ Model }} & \multicolumn{2}{|c|}{$\begin{array}{l}\text { Coefficients } \\
\text { unstandardized }\end{array}$} & \multirow{2}{*}{$\begin{array}{l}\text { standardized } \\
\text { Coefficients } \\
\text { beta }\end{array}$} & \multirow[b]{2}{*}{$\mathrm{T}$} & \multirow[b]{2}{*}{ Sig. } \\
\hline & & $\mathrm{B}$ & $\begin{array}{l}\text { Std. } \\
\text { Error }\end{array}$ & & & \\
\hline & (Constant) & -1.021 &, 162 & & -6.286 &, 000 \\
\hline & Biological asset intensity &, 230 &, 042 & , 450 & 5,498 &, 000 \\
\hline & size of company &, 119 &, 013 &, 801 & 9.091 &, 000 \\
\hline & concentration of ownership &,- 001 & .001 &,- 113 & -1.291 &, 201 \\
\hline & type KAP &,- 038 & .016 &,- 202 & -2.349 &, 022 \\
\hline
\end{tabular}

\section{1) Testing variable coefficients X1 (Biological asset intensity)}

H0. Biological asset intensity no effect on the disclosure of biological assets

H1. Biological asset intensity affects the biological asset disclosure

In this study biological asset intensity have $\mathrm{t}$ count $>\mathrm{t}$ table $(5,498>1.6679)$ and significant $(0.00<0.05)$, so $\mathrm{HO}$ rejected and $\mathrm{H1}$ be accepted. Thus, it can be concluded that biological asset intensity (X1) partially positive and significant impact on the disclosure of biological assets the agricultural sector companies listed on the Indonesian Stock Exchange (BEI) in the period 2012-2015.

2) A testing coefficient of X2 (company size)

H0. Company size does not affect the biological asset disclosure

H2. Company size affects the biological asset disclosure 
Size of company value $t>t$ table $(9.091>1.6679)$ and significant $(0.00<0.05)$, so Ho rejected and $\mathbf{H} 2$ be accepted. Thus, it can be concluded that company size(X2) partially positive and significant impact on the disclosure of biological assets the agricultural sector companies listed on the Indonesian Stock Exchange (BEI) in the period 20122015.

\section{3) Testing X3 variable coefficient (Concentration of ownership)}

H0. A concentration of ownership does not affect the disclosure of biological assets

H3. A concentration of ownership affect the disclosure of biological assets

Concentration of ownership has a value $t<t$ table $(-1.291<1.6679)$ and significant (0.201> 0.05), so $\mathbf{H O}$ be accepted and $\mathbf{H 3}$ rejected. Thus, it can be concluded that the ownership concentration (X3) partially no effect on disclosure of biological assets the agricultural sector companies listed on the Indonesian Stock Exchange (BEI) in the period 2012-2015. Negative T value indicates that the concentration of ownership has a relationship with Beta in the opposite direction.

4) Testing $X 4$ variable coefficient (Type KAP)

H0. KAP type does not affect the biological asset disclosure

H4. KAP type of biological effect on asset disclosure

KAP has a value type $\mathrm{t}<\mathrm{t}$ table $(-2.349<1.6679)$ and significant $(0.02<0.05)$, so Ho rejected and $\mathrm{H} 4$ be accepted. Thus, it can be concluded that kind of $\mathrm{KAP}(\mathrm{X} 4)$ partially significant negative effect on disclosure of biological assets the agricultural sector companies listed on the Indonesian Stock Exchange (BEI) in the period 2012-2015. Negative T value indicates that kind of KAP has a relationship with Beta in the opposite direction.

\subsection{Discussion Hypothesis Testing Results}

\subsubsection{Effect of Biological Asset Intensity on Biological Assets Disclosure}

Theory supports it explains that biological assets are animal and plant life. This asset is a significant asset to the agricultural company, then as a significant asset to the company's investment proportion of its biological assets are also disclosed in the 
company's annual report. Stakeholder theory explains that the management company is expected to perform activities that are considered significant by stakeholders and report back on those activities to stakeholders. In a study by Silva et al. (2012) explain that the reporting of biological assets ensure compliance with the disclosure in order to provide information to users of financial statements. So, biological asset intensity significant positive effect on the disclosure of biological assets.

\subsubsection{The influence of company size on Biological Assets Disclosure}

It is supported by the theory of Jensen and Meckling (1976) which stated that large companies tend to have a percentage of capital and the cost of a larger agency that requires the disclosure of information to stakeholders, particularly financial analysts. Furthermore, company significant companies usually observed by a group of stakeholders and therefore disclosure practices that positively predicted if companies are trying to minimize the political costs (Ihyaul, 2009). So, company size significant positive effect on the disclosure of biological assets.

\subsubsection{Effect of concentration of ownership of Biological Assets Disclosure}

It is supported by the theory cited by Goriz and Fumas (1996), the type of ownership and control of a company is divided into two. First, the company is owned by many shareholders. Second, the company owned and controlled by management. Like, concentrated ownership is not too much attention to the disclosure of biological assets to be disclosed in the annual report because it is not very important, related to standards not require it to be disclosed and will incur additional costs for the manager later. Furthermore, a high concentration of ownership may also pose a unilateral decision for their voting rights (voting rights) in the GMS, so that the results achieved are not optimal. So, a concentration of ownership effect on the disclosure of biological assets.

\subsubsection{The influence of the type of KAP on Biological Assets Disclosure}

It is supported by the theory Craswell and Taylor (1992), quoted by Falikhatun et al. (2009). Use of the Public Accounting Firm (KAP), which is affiliated with the big four 
accounting firm that audits the company as agriculture does not warrant the disclosure of biological assets for more. Evident from the results showed scores of biological asset disclosures in companies audited by the accounting firm that is affiliated with the big four, or who are not affiliated with the big four not much different. This is because the disclosure of biological assets related standards recently passed in December 2015 and will become effective in January 2018. So, what type KAP negatively affect the disclosure of biological assets.

\section{Conclusions, Implications and Limitations}

\subsection{Conclusion}

Based on the results of the testing that has been done can be concluded as follows: (1). Biological asset intensity significant positive effect on the disclosure of biological assets in the agricultural company listed in Indonesia Stock Exchange period 2012 - 2015, (2)

The size of the company significant positive effect on the disclosure of biological assets in the agricultural company listed in Indonesia Stock Exchange period 2012 - 2015, (3) A concentration of ownership does not affect the disclosure of biological assets in the agricultural company listed in Indonesia Stock Exchange period 2012 - 2015, (4) Type KAP significant negative effect on the disclosure of biological assets in an agricultural company listed in Indonesia Stock Exchange period 2012 - 2015

\subsection{Implication}

The results of this research will have implications for the management of the company. Wherein, the management company is expected to pay more attention to the completeness of the disclosure of biological assets related to agricultural standards despite recently passed in Indonesia in the form of IAS 69 by the end of 2015. However, this standard will be useful starting January 1, 2018. Therefore, the disclosure of which can make the company is easy to attract investors and convince creditors if the company wants to make loans. 


\subsection{Limitations}

There are several limitations to this study: (1) This study only tested the biological asset variable intensity, company size, concentration of ownership and type of KAP. There are still many possibilities for other variables that affect the disclosure of biological assets examples such as the company's growth, foreign shareholders, (2) In the study period of 2012-2015, it is only related to the annual report, and financial statements audited for the year 2016 to the current data in this study finished processed are still many companies that have not been published.

\subsection{Suggestion}

Suggestions of research for the future: (1) For further research is expected to test other variables that may affect the disclosure of biological assets, (2) To the researchers' observation period are expected to use the most recent year and extend the observations of the study in order to provide a current picture regarding disclosure of biological assets, (3) Expected for agricultural companies to pay more attention and reveal more detailed biological assets managed by the company. Starting from the initial recognition, harvest, produced in agricultural products, until the asset is experiencing discontinuation due to death or not proliferate anymore. So that financial statement users could know more clearly.

\section{Reference}

Adita and Kiswara. 2012. Analysis of Application of International Accounting Standard (IAS) 41 on PT. Sampoerna Agro Tbk. Diponegoro Journal of Accounting Vol 1, 2

BPS (Central Bureau of Statistics) statistics related to agriculture. 2015-2016

Choi, F. 2005. The International Accounting. New Jersey: Prentice Hall

Darmawati, Deni. 2006. "Effect of Company Characteristics and Regulatory Factors of Quality Implementation of Good Corporate Governance". Accounting National Symposium IX. 23 to 26 December 2006. Padang.

Daske, H., et al. 2008. Mandatory IFRS Reporting around the World: Early Evidence on the Economic Consequences. Journal of Accounting Research, 46 (5), 1085-1142. 
Debby, Princess Eltanto. 2014. Treatment of Accounting and PPH Top Industrial Agriculture. Tax And Accounting Review, Vol. 4, no.1

Ding et al. 2007. Differences between domestic accounting standards and IAS: measurement, determinants, and implications. Journal of Accounting and Public Policy, 26, 1-38.

Falikhatun, et al. 2009. The Effects of Corporate Governance on the Intellectual Capital Disclosure: An Empirical Study from the Banking Sector in Indonesia. Article.Surakarta: University of March

Financial Accounting Standards Board (FASB). 1984. "Statement of Financial Accounting Concepts No. 5: Recognition and Measurement in Financial Statements of Business Enterprises". Stamford. Connecticut.

Freeman, RE 1984. Strategic Management: A Stakeholder Approach, Boston: Pitman.

Freedman, M. and B. Jaggi. 2005. Global Warming, Commitment to the Kyoto Protocol, and Accounting Disclosures by The Largest Global Public Firms from polluting Industries. The International Journal of Accounting 40 pp: 215-232

Ghozali, Imam. 2016. Applications Multivariate Analysis with SPSS Advanced. Semarang: Diponegoro University Publishing Firm

Goncalves Routes, and Patricia Lopes. 2014. Determinants of Agricultural Firm-Specific Financial Reporting. University of Porto: Vol 110 h. 470-481

Gorriz, CG and VS Fumas. Owner 1996. Structure and Firm Performance: Some Empirical Evidence from Spain. Managerial and Decision Economics, 17. pp: 575-586

Healy, Paul M., and Krishna G. Palepu. 2001. "Information Asymmetry, Corporate Disclosure, and the Capital Markets: A Review of the Empirical Literature Disclosure". Journal of Accounting and Economics, 31 (1-3), 405-440

Hodgdon, et al. 2009. "Compliance with International Financial Reporting Standards and auditor choice: New evidence on the importance of the statutory audit". The International Journal of Accounting, 44, 33-55

IAS (International Accounting Standard) 41-Agriculture

Ihyaul Ulum. 2009. Intellectual Capital concepts and empirical studies. Graha Science: Yogyakarta

Jensen, M. and Meckling, W. 1976. Theory of the firm: Managerial behavior, agency costs, and ownership structure. Journal of Financial Economics. 3 (4), 305-360

Machfoedz, Mas'ud. Characteristic of 1994. Financial Ratio Analysis Earning And The Prediction Of Change In Indonesia. Manage 7 pp: 114-133 
Nuryaman. 2009. Effect of concentration of ownership, company size, and Corporate Governance Mechanism Against Voluntary Disclosure. Journal of Accounting and Finance of Indonesia, Vol. 61

Owusu-Ansah, S. 1998. The impact of corporate attributes on the extent of mandatory disclosure and reporting by listed companies in Zimbabwe. International Journal of Accounting. $33(5), 605-631$

Paton, Andrew W. 1962. Accounting Theory. Second edition, USA

SFAS (Statement of Financial Accounting Standards) 69: Agriculture

Santoso, Singgih. 2010. Multivariate Statistics, Revised Edition. Jakarta: PT. Gramedia

Silva, R., et al. 2012. The convergence with international accounting standards: Analysis of Biological Assets IAS 41. Disclosure of the University of Porto.

\section{Appendix}

Table 2.1

\section{Biological Assets Disclosure Item}

\begin{tabular}{|c|c|c|}
\hline Paragraph & Disclosure Index & Score \\
\hline & Mandatory Items: & \\
\hline 40 & Gains or losses arising during the period: & \\
\hline 40 & The initial recognition of biological assets & 1 \\
\hline 40 & The initial recognition of the results of agriculture & 1 \\
\hline 40 & Changes in fair value less cost to sell & 1 \\
\hline 41 & An overview of each group of biological assets & 1 \\
\hline 42 & Explanation paragraph 41 & 1 \\
\hline 42 & Explanation of measurement 41 & 1 \\
\hline 46 & Explanation of the company's activities with each group of biological assets & 1 \\
\hline 46 & Explanation stages of non-financial measurements: & \\
\hline 46 & Assets that are available at the end of the period & 1 \\
\hline 46 & Results of agriculture during the period & 1 \\
\hline 47 & $\begin{array}{l}\text { Assumptions and methods used in determining the fair value of each of the } \\
\text { agricultural products at the point of harvest and each group of biological assets }\end{array}$ & 1 \\
\hline 48 & The fair value less costs to sell agricultural products harvested in the period & 1 \\
\hline 49 & Information related to biological assets that are restricted or pledged & 1 \\
\hline 49 & The commitment to the development or acquisition of biological assets & 1 \\
\hline 49 & Financial risk management strategies related to biological assets & 1 \\
\hline
\end{tabular}




\begin{tabular}{|c|c|c|}
\hline Paragraph & Disclosure Index & Score \\
\hline 50 & $\begin{array}{l}\text { Adjustments related to changes in the carrying amount of biological assets at the } \\
\text { beginning and end of the period }\end{array}$ & 1 \\
\hline \multirow[t]{2}{*}{50} & Reconciliation covering desegregate & 1 \\
\hline & Additional disclosures when fair value can not be measured reliably & \\
\hline 54 & $\begin{array}{l}\text { Entities measure and reveal the biological assets is based on the fees they charge } \\
\text { minus accumulated depreciation and accumulated impairment losses }\end{array}$ & \\
\hline 54 & Overview of biological assets & 1 \\
\hline 54 & An explanation of why fair value can not be measured reliably & 1 \\
\hline 54 & Estimated fair value level mismatch & 1 \\
\hline 54 & Depreciation methods used & 1 \\
\hline 54 & Useful lives or depreciation rates used & 1 \\
\hline 54 & $\begin{array}{l}\text { The gross carrying amount and the accumulated depreciation (accumulated } \\
\text { impairment losses) at the beginning and end of the period }\end{array}$ & 1 \\
\hline 55 & The recognition of gain or loss on the sale of biological assets & 1 \\
\hline 55 & Impairment losses, related termination & 1 \\
\hline 55 & Reversal of impairment losses related to a termination & 1 \\
\hline 55 & Depreciation related to a termination & 1 \\
\hline 56 & $\begin{array}{l}\text { Disclosure of related entities - The fair value of biological assets previously } \\
\text { measured at cost less accumulated depreciation defined and impairment losses } \\
\text { becomes reliably measurable during the current period }\end{array}$ & \\
\hline 56 & Overview of biological assets & 1 \\
\hline 56 & An explanation of why fair value has been measured reliably & 1 \\
\hline 56 & Effect of changes & 1 \\
\hline 57 & Disclosure of Government Grants-linked entities & \\
\hline 57 & government grants & 1 \\
\hline 57 & Recognition related nature and extent of government grants in financial statements & 1 \\
\hline 57 & Conditions to be met and other contingency attached to government grants & 1 \\
\hline \multirow[t]{2}{*}{57} & A significant reduction in the level of government grants & 1 \\
\hline & Non-Mandatory but recommended items: & \\
\hline 43 & Overview calculating each group of biological assets, which distinguishes it: & \\
\hline 43 & Consumable and bearer assets & 1 \\
\hline 43 & Mature and immature assets & 1 \\
\hline
\end{tabular}


The Indonesian Journal of Accounting Research - Jan, Vol. 21, No.1, 2018

\begin{tabular}{|l|l|l|}
\hline Paragraph & Disclosure Index & Score \\
\hline 51 & $\begin{array}{l}\text { Total change in fair value less costs to sell, affect the profit or loss due to physical } \\
\text { changes and price changes }\end{array}$ & 1 \\
\hline 51 & Biological assets convey this information & 1 \\
\hline NA & information on the assessment of the effects & 1 \\
\hline NA & Further information & 1 \\
\hline NA & $\begin{array}{l}\text { An assumption of future prices and costs, as well as express sensitivity analysis } \\
\text { with multiple parameters }\end{array}$ & 1 \\
\hline
\end{tabular}

Source: Journal Procedia-Social and Behavioral Science 110 (2014) 